\title{
Influences of Limited Ammonium Nitrogen and Water Temperature on the Urban Stream Restoration Using Bacterial Technology - View from the Perspective of Numerical Modelling
}

\author{
Doddi Yudianto, Yuebo Xie \\ National Engineering Research Center of Water Resources Efficient Utilization and Engineering Safety, \\ Hohai University, Nanjing, China \\ E-mail:doddi_yd@yahoo.com \\ Received December 2, 2009; revised January 5, 2010; accepted January 19, 2010
}

\begin{abstract}
To complete the previously information issued on the feasibility study and some technical challenges identified from the application of bacterial technology, this study presents another characteristics of numerical output as the bacterial growth is now also limited to ammonium nitrogen and water temperature. Based on the results obtained, it is found that the degradation of readily biodegradable COD will be much slower because of lower bacterial growth. At certain period, the COD concentration will increase and be plotted higher later on compared to the model which is limited only to substrate and oxygen. Besides the ammonium nitrogen, other parameters i.e. particulate products from COD decay and particulate degradable organic nitrogen will also increase soon after certain time. Considering the increase of ammonium nitrogen as it is also converted to nitrate nitrogen, it can be predicted that some algae may show up during the treatment processes. When the model is simulated under different water temperature, slower biodegradation process is presented at lower water temperature. Because the bacteria grow better at higher water temperature, more oxygen is then required. Finally, from this study, it is also identified that the artificial mixing and addition of oxygen at initial stage of treatment will considerably influence the restoration.
\end{abstract}

Keywords: Stream Restoration, Bacterial Technology, Polluted Urban Streams, Numerical Modelling, MATLAB

\section{Introduction}

As stream has always been the recipient of wastes discharge from human activities, be it domestic sources, industrial or agricultural effluents or mining process waters, the massive increase of industrial productions accompanied by high growth of large urban populations has led to severe water pollution problems for over the last two centuries. Such situation was found to be even worse in many lesser developed countries and some of the megalopolises with unbridled population growth and uncontrolled industrial development [1-2].

Because of its urgent necessity to find solutions for water pollution problems, there have been some methods and technologies developed and applied for the last few years. Started by the application of re-aeration

Identify applicable sponsor/s here. (sponsors) using series of weir [3-5], shifting the effluent discharges location [6], pumping air into the water body using the local oxygenator [3,7] and the implementation of constructed wetland [8-13], it has been a while before the bacterial technology was then introduced to solve similar problems. In China, such technology has been implemented recently for treating the polluted lake [14] and influent of wastewater treatment plant [15]. It is also great to know that the practical application of this technology was found to be successful in speeding up the recovery processes of some streams in Shenzhen City, China. The final concentrations of BOD and COD after the treatment were informally reported to be less than 5.00 and $20.00 \mathrm{mg} \mathrm{L}^{-1}$ respectively.

Along with the practical implementation of this bacterial technology for stream restoration purpose, the feasibility and some technical challenges in relation to 
such technology have been previously issued by "in press" [5] and "unpublished" [16]. As it is previously stated that treating seriously polluted surface water through the self-purification process may result one or more unwanted end products [17], here other limiting parameters to the biodegradation processes i.e. ammonium and different water temperature are now included in this study to complete the feasibility information of bacterial technology from the perspective of numerical modelling. At the mean time, some field data from the restoration and monitoring project of Xuxi River in Wuxi City are still under collection and laboratory test. To be able to collect the data from the field site, as information, the process is not only influenced by technical factors but also administrative procedures. Under the same project, the authors have experienced more than a year to obtain the legal notice and set appropriate conditions to discharge certain amount of selected bacteria to the chosen stream reach. Because MATLAB has been proved to be highly accurate [18] and widely implemented in many fields of water quality modelling [5,19-24], therefore it is then selected to be used for all the simulations in this study.

\section{Methodology}

In order to understand the biodegradation processes occur as result of the implementation of bacterial technology, a combination of Streeter Phelps and some kinetic equations used in Activated Sludge Model No.1 (ASM-1) is employed here. Due to influences of hydraulics properties, the role of dispersion term in transport model becomes crucial [25-26] and therefore the flow velocity and mixing parameters are also included in the model simulations and further evaluated in relation with some selected parameters in both distance and time. Besides the readily biodegradable substrate and oxygen, ammonium nitrogen and different water temperatures are considered here to provide broader views. Furthermore, as the ASM-1 was basically developed on the basis of Chemical Oxygen Demand (COD) with homogeneous heterotrophs, all coefficients required in this study are adopted from the previous related studies. To simplify the case, it is also assumed here that all degradation processes involved occur at neutral $\mathrm{pH}$.

\section{Model Development}

In most cases of natural stream restoration, besides the readily biodegradable COD and oxygen, the ammonium nitrogen $\left(S_{N_{4}}\right)$ also plays crucial role. As it can be initially predicted, when ammonium nitrogen is considered as another limiting parameter to the model, the results may come up with new characteristics since the bacterial growth is even lowered down to certain extent.

\subsection{Brief Description of ASM-1}

Generally, there are 13 substances and 8 different processes incorporated in the ASM-1. Although this model has been extended to incorporate more fractions of COD, the original model is probably still the most widely used for describing the biodegradation processes [27-28]. In the process of its development, COD was selected as the suitable parameter for defining the carbon material as it provides a link between electron equivalents in the organic substrate, bacteria, and oxygen utilized.

Representing the dynamic processes, the readily biodegradable of COD $\left(S_{S}\right)$ is used for the growth of heterotrophic bacteria $\left(X_{H}\right)$ and the balance is oxidized for energy giving rise to an associated oxygen demand. Here, ammonia $\left(S_{\mathrm{NH}_{4}}\right)$ is used as the nitrogen source for synthesis and incorporated into the cell mass. Both concentration of SS and oxygen may be rate limiting for the growth process as it is clearly described using the Monod kinetics. This process is generally the main contributor to the generation of bacteria and removal of COD even though modifications may be needed to satisfy the conditions of nitrification [29]. As presented in this study, some related processes to the bacterial growth are also limited by ammonia $\left(\mathrm{S}_{\mathrm{NH}_{4}}\right)$.

In the absence of oxygen, the heterotrophs are capable of using nitrate as the terminal electron acceptor with SS as substrate. The process will lead to a production of heterotrophs and nitrogen gas (denitrification). In ASM-1, the ammonia is oxidized to nitrate via a single step process (nitrification) resulting in production of autotrophs $\left(X_{A}\right)$ and giving rise to an associated oxygen demand. Because of the low yield of autotrophic nitrifiers, there is only small effect given to the formation of autotrophs. The situation for autotrophs in fact is simpler since the autotrophs do not grow in anoxic environment.

Not only growths, in this model, the decay of both heterotrophs and autotrophs are modelled according to the death regeneration hypothesis. The organisms will basically die at certain rate and a portion of the material is considered to give addition to the value of particulate products $\left(X_{P}\right)$ and slowly biodegradable substrate $\left(X_{S}\right)$. The organic nitrogen associated with $X_{S}$ becomes available as particulate organic nitrogen. Along to those processes, the biodegradable soluble organic nitrogen $\left(S_{N D}\right)$ is also converted to ammonia in a first order process mediated by the active heterotrophs. In addition, the $X_{S}$ is slowly broken down to produce $S_{S}$ under aerobic and anoxic conditions.

\subsection{Kinetic Equations Applied}

By adopting the basic concept of self purification and some equilibria employed in ASM-1 based on the Monod kinetics, and as the bacteria and other variables are assumed here to migrate with flow, the complete 
biodegradation processes can be mathematically defined as follows.

Readily biodegradable COD $\left(S_{S}\right)$ :

$$
\begin{aligned}
& \frac{d S_{S}}{d t}=-u_{x} \frac{d S_{S}}{d x}+E_{x} \frac{d^{2} S_{S}}{d x^{2}}-\frac{\mu_{\max H}}{Y_{X H / s S}} \frac{S_{S}}{K_{S}+S_{S}} \\
& {\left[\frac{C}{K_{O H}+C} \frac{S_{N_{4}}}{K_{N_{4}}+S_{N_{4}}}+\eta_{g} \frac{K_{O H}}{K_{O H}+C} \frac{S_{\mathrm{NO}_{3}}}{K_{\mathrm{NO}_{3}}+S_{\mathrm{NO}_{3}}}\right] X_{H}} \\
& +k_{h} \frac{X_{S} / X_{H}}{K x+}\left[\frac{C}{X_{S} / X_{H}}+\eta_{h} \frac{K_{O_{2}}}{K_{\mathrm{O}_{2}}+C} \frac{S_{\mathrm{NO}_{3}}}{K_{\mathrm{NO}_{3}}+S_{\mathrm{NO}_{3}}}\right] X_{H}
\end{aligned}
$$

Active heterotrophic bacteria $\left(X_{H}\right)$ :

$$
\begin{aligned}
& \frac{d X_{H}}{d t}=-u_{x} \frac{d X_{H}}{d x}+E_{x} \frac{d^{2} X_{H}}{d x^{2}}+\mu_{\operatorname{maxH}} \frac{S_{S}}{K_{S}+S_{S}} \\
& {\left[\frac{C}{K_{O H}+C} \frac{S_{N_{4}}}{K_{N_{4}}+S_{N_{4}}}+\eta_{g} \frac{K_{O H}}{K_{O H}+C} \frac{S_{N O_{3}}}{K_{N O_{3}}+S_{N O_{3}}}\right] X_{H}-k_{d H} X_{H}{ }^{n H}}
\end{aligned}
$$

Active autotrophic bacteria $\left(X_{A}\right)$ :

$$
\frac{d X_{A}}{d t}=-u_{x} \frac{d X_{A}}{d x}+E_{x} \frac{d^{2} X_{A}}{d x^{2}}+\mu_{\max A} \frac{S_{N H_{4}}}{K_{N H_{4}}+S_{N H_{4}}} \frac{C}{K_{O A}+C} X_{A}-k_{d A} X_{A}{ }^{n A}
$$

Ammonium nitrogen $\left(S_{\mathrm{NH}_{4}}\right)$ :

$$
\begin{aligned}
& \frac{d S_{N H_{4}}}{d t}=-u_{x} \frac{d S_{N H_{4}}}{d x}+E_{x} \frac{d^{2} S_{N_{4}}}{d x^{2}}-i X_{B} \mu_{\operatorname{maxH}} \frac{S_{S}}{K_{S}+S_{S}} \\
& {\left[\frac{C}{K_{O H}+C} \frac{S_{N H_{4}}}{K_{N H_{4}}+S_{N H_{4}}}+\eta_{g} \frac{K_{O H}}{K_{O H}+C} \frac{S_{N O_{3}}}{K_{N O_{3}}+S_{N O_{3}}}\right] X_{H}+k_{a N} S_{N D} X_{H}} \\
& -\mu_{\max }\left[i X_{B}+\frac{1}{Y_{N Q} / X A}\right] \frac{S_{N H_{4}}}{K_{N H_{4}}+S_{N H_{4}}} \frac{C}{K_{O A}+C} X_{A}
\end{aligned}
$$

Nitrate nitrogen $\left(\mathrm{S}_{\mathrm{NO}_{3}}\right)$ :

$$
\begin{aligned}
& \frac{d S_{\mathrm{NO}_{3}}}{d t}=-u_{x} \frac{d S_{\mathrm{NO}_{3}}}{d x}+E_{x} \frac{d^{2} S_{\mathrm{NO}_{3}}}{d x^{2}}- \\
& \mu_{\max H} \eta_{g} \frac{1-Y_{\mathrm{XH} / S \mathrm{SS}}}{2.86 Y_{\mathrm{XH} / s \mathrm{~S}}} \frac{S_{S}}{K_{S}+S_{S}} \frac{K_{\mathrm{OH}}}{K_{\mathrm{OH}}+C} \frac{S_{\mathrm{NO}_{3}}}{K_{\mathrm{NO}_{3}}+S_{\mathrm{NO}_{3}}} X_{H} \\
& +\frac{\mu_{\operatorname{maxA}}}{\mathrm{Y}_{\mathrm{NO}_{3} / \mathrm{XA}}} \frac{S_{\mathrm{NH}_{4}}}{K_{\mathrm{NH}_{4}}+S_{\mathrm{NH}_{4}}} \frac{C}{K_{\mathrm{OA}}+\mathrm{C}} X_{A}
\end{aligned}
$$

Slowly biodegradable COD $\left(X_{S}\right)$ :

$$
\begin{aligned}
& \frac{d X_{S}}{d t}=-u_{x} \frac{d X_{S}}{d x}+E_{x} \frac{d^{2} X_{S}}{d x^{2}}+\left(1-f_{p}\right) k_{d H} X_{H}+\left(1-f_{p}\right) k_{d A} X_{A} \\
& -k_{h} \frac{X_{S} / X_{H}}{K_{X}+}\left[\frac{C}{X_{S} / X_{H}}+\eta_{h} \frac{K_{O H}}{K_{O H}+C} \frac{S_{\mathrm{NO}_{3}}}{K_{\mathrm{NO}_{3}}+S_{\mathrm{NO}_{3}}}\right] X_{H}
\end{aligned}
$$

Particulate products from COD decay $\left(X_{P}\right)$ :

$$
\frac{d X_{P}}{d t}=-u_{x} \frac{d X_{P}}{d x}+E_{x} \frac{d^{2} X_{P}}{d x^{2}}+f_{p} k_{d H} X_{H}+f_{p} k_{d A} X_{A}
$$

Soluble degradable organic nitrogen $\left(S_{N D}\right)$ :

$$
\begin{aligned}
& \frac{d S_{N D}}{d t}=-u_{x} \frac{d S_{N D}}{d x}+E_{x} \frac{d^{2} S_{N D}}{d x^{2}}-k_{a N} S_{N D} X_{H} \\
& +k_{h} \frac{X_{N D} / X_{H}}{K_{X}+X_{S} / X_{H}}\left[\frac{C}{K_{O H}+C}+\eta_{h} \frac{K_{O H}}{K_{O H}+C} \frac{S_{\mathrm{NO}_{3}}}{K_{\mathrm{NO}_{3}}+S_{N O_{3}}}\right] X_{H}
\end{aligned}
$$

Particulate degradable organic nitrogen $\left(X_{N D}\right)$ :

$$
\begin{aligned}
& \frac{d X_{N D}}{d t}=-u_{x} \frac{d X_{N D}}{d x}+E_{x} \frac{d^{2} X_{N D}}{d x^{2}}+\left(i X_{B}-f_{p} i X_{P}\right)\left(k_{d H} X_{H}+k_{d A} X_{A}\right) \\
& -k_{h} \frac{X_{N D} / X_{H}}{K_{X}+X_{S} / X_{H}}\left[\frac{C}{K_{O H}+C}+\eta_{h} \frac{K_{O H}}{K_{O H}+C} \frac{S_{N O_{3}}}{K_{N O_{3}}+S_{N O_{3}}}\right] X_{H}
\end{aligned}
$$

Dissolved oxygen $(C)$ :

$$
\begin{aligned}
& \frac{d C}{d t}=-u_{x} \frac{d C}{d x}+E_{x} \frac{d^{2} C}{d x^{2}}+k_{a}\left(C_{s}-C\right) \\
& -\mu_{\max } H \frac{1-Y_{X H} / s s}{Y_{X H} / s s} \frac{S_{S}}{K_{S}+S_{S}}\left(\frac{C}{K_{O H}+C} \frac{S_{N H_{4}}}{K_{N_{4}}+S_{N H_{4}}}\right) X_{H} \\
& -\mu_{\max A} \frac{4.57-\mathrm{Y}_{\mathrm{NO}_{3} / \mathrm{XA}}}{\mathrm{Y}_{\mathrm{NO}_{3} / \mathrm{XA}}} \frac{S_{\mathrm{NH}_{4}}}{K_{\mathrm{NH}_{4}}+S_{\mathrm{NH}_{4}}} \frac{C}{K_{O A}+C} X_{A}
\end{aligned}
$$

where

$Y_{X H / S S}:$ mg biomass COD formed per mg COD removed

$F_{p} \quad:$ mg debris COD (mg biomass COD) $)^{-1}$

$i_{X B} \quad: \mathrm{mg} \mathrm{N}(\mathrm{mg} \mathrm{COD})^{-1}$ in active biomass

$i_{X P} \quad: \mathrm{mg} \mathrm{N}(\mathrm{mg} \mathrm{COD})^{-1}$ in active debris

$Y_{\mathrm{NO}_{3} / \mathrm{XS}}: \mathrm{mg}$ biomass COD formed per mg $\mathrm{N}$ oxidized

$\mu_{\max H}$ : heterotrophic max specific growth rate

$\mu_{\max A}$ : autotrophic max specific growth rate

$k_{d H} \quad$ : decay coefficient of heterotroph bacteria

$k_{d A} \quad$ : decay coefficient of autotroph bacteria

$K_{S} \quad$ : half saturation coefficient of degradable dissolves in heterotrophic growth

$K_{O H}$ : half saturation coefficient of oxygen in heterotrophic growth

$K_{\mathrm{NO}_{3}}$ : half saturation coefficient of $\mathrm{NO}_{3}$ in anoxic heterotrophic growth

$K_{X} \quad$ : half saturation coefficient of organic in hydrolysis

$K_{N_{4}}$ : half saturation coefficient of $\mathrm{NH}_{4}$ in growth of heterotrophs

$K_{O A} \quad$ : half saturation coefficient of oxygen in nitrifying bacterial growth

$k_{h} \quad$ : maximum hydrolysis rate constant at $20{ }^{\circ} \mathrm{C}$

$k_{a N}:$ ammonification rate by anoxic hydrolysis of heterotrophs

$k_{a} \quad$ : reaeration coefficient

$\eta_{g} \quad$ : correction factor for anoxic growth of heterotrophs

$\eta_{h} \quad$ : correction factor for anoxic hydrolysis

\subsection{Computation of Mixing Coefficient and Reaeration Coefficient}

Literally, there are some available equations that can be used to technically predict the longitudinal mixing in a stream such as McQuivey and Keefer (1974), Fischer 
(1975), Jain (1974), Liu (1977), Seo and Cheong (1998), and Deng et al. (2001) [26]. Although most of these equations have been widely applied in many research works, however, [26] showed that such equations result a wide range of values for the same hydraulic characteristics of in bank flow. Being the most accurate and mostly cited one [25], the predictive equation of Seo and Cheong is then chosen in this paper and defined as follows.

$$
\begin{gathered}
E_{x}=5.915\left[\frac{u_{x}}{u_{*}}\right]^{1.428}\left[\frac{W}{H}\right]^{0.62} H u * \\
u_{x}=\frac{1}{n}\left(\frac{A}{P}\right)^{2 / 3} S^{1 / 2}
\end{gathered}
$$

where

$W \quad$ : width of water surface (L)

$H \quad$ : average water depth (L)

$u_{x} \quad$ : average water depth $\left(\mathrm{LT}^{-1}\right)$

$u_{*} \quad:$ shear/friction velocity $\left(\mathrm{LT}^{-1}\right)$

$A$ : wet area of channel cross-section $\left(\mathrm{L}^{2}\right)$

$P \quad$ : wet perimeter (L)

$S \quad$ : channel bed slope

$n \quad$ : bed roughness coefficient of Manning

Generally, there are numerous available formula for estimating the reaeration coefficient such as $\mathrm{O}^{\prime}$ Connor and Dobbins (1958), Churchill, et al. (1962), Owens, et al. (1964), Tsivoglou and Neal (1976), USGS - Melching and Flores (1999), and Thackston and Dawson (2001) [30-31]. However, since the reaeration formula proposed by O'Connor and Dobbins (1958) is still widely used by many recent water quality models such as QUAL2Kw, WASP, et cetera, it is then selected and applied here for model simulations.

$$
k_{a}=\frac{3.93 u_{x}^{0.5}}{H^{1.5}}
$$

\subsection{Numerical Computation}

As the above problems are formulated in the form of partial differential equations (PDEs) and since there have been some evidences of high accuracy of numerical solution given by MATLAB using the pdepe solver function, it was therefore used in this study to conduct the whole simulations. Generally, the necessity introducing this solver method is because it offers more possibilities and flexibilities for both beginners and experts to evaluate or even invent a model since there has been a numerous number of mathematic functions developed inside MATLAB.

Besides it can be applied for broader aspect of numerical computation, in MATLAB, the PDEs with various forms of additional terms can also be easily included and solved as a system. The pdepe solver function basically converts the PDEs to ordinary differential equations (ODEs) using a second order accurate spatial discretiza- tion and is applied mostly for initial-boundary value problems consist of systems of parabolic and elliptic PDEs in one space variable and time. In this scheme, the initial conditions are allowed to be space dependent and boundary conditions to be time dependent. In solving system of PDEs, the pdepe solver function is generally written in the form of

$$
c\left(x, t, u, \frac{\partial u}{\partial x}\right) \frac{\partial u}{\partial t}=x^{-m} \frac{\partial u}{\partial x}\left(x^{m} f\left(x, t, u, \frac{\partial u}{\partial x}\right)\right)+s\left(x, t, u, \frac{\partial u}{\partial x}\right)(14)
$$

Using pdepe MATLAB, various boundary conditions can also be flexibly formulated either as Dirichlet, Neumann or even Cauchy/Robin. Here, as the downstream boundary of the model is theoretically equal to zero for positive infinity, Neumann condition is considered for all model simulations.

\section{Model Applications}

The developed numerical model was applied to a straight and uniform rectangular channel for in bank flow case where the hydraulic dimensions used are; channel width $\mathrm{B}_{1}=5.00 \mathrm{~m}$, roughness Manning coefficient $\mathrm{n}=0.020$, and bed slope of 0.00001 . The flow rate applied for all model simulations was $0.50 \mathrm{~m}^{3} \mathrm{~s}^{-1}$. Furthermore, to understand the impact of bacteria on COD removal, the concentration of heterotrophs used in the simulations is $25.00 \mathrm{mgL}^{-1}$. The autotrophs itself is set as constant of $5.00 \mathrm{mgL}^{-1}$. To simulate the biodegradation processes, this study has made use of some parameters employed by Jeppsson (1996) for modelling the activated sludge processes under different temperature. The complete parameters values and data are presented in Tables 1-3.

\section{Results and Discussion}

Based on the simulation results obtained, it can be noticed that when the bacterial growth became lower due to limited readily biodegradable COD $\left(S_{S}\right)$, oxygen $\left(\mathrm{O}_{2}\right)$ and ammonium nitrogen $\left(\mathrm{S}_{\mathrm{NH}_{4}}\right)$, the degradation of COD

will be much slower (Figure 1). As clearly described in Figure 2, a contrast characteristic of COD profiles is shown in association with different limiting parameters applied to the model. When the ammonium is included as another limiting parameter, the COD concentration will increase at certain period and be plotted higher than if the model is limited only to substrate and oxygen. In addition, the bacteria will also grow slower and perform lower concentration.

Besides the ammonium nitrogen, other parameters i.e. particulate products from COD decay and particulate degradable organic nitrogen will also increase soon after certain time. As shown in Figure 3, the ammonium nitrogen starts to decrease at 0.7 day and at the same time it is converted to nitrate nitrogen. Although it is simulated under different limiting parameters but the ammonium-nitrogen will be firstly lowered the lowest point 
Table 1. Typical values of ASM-1 parameters at neutral $\mathrm{pH}$.

\begin{tabular}{|c|c|c|c|}
\hline Model Parameters & $20^{\circ} \mathrm{C}$ & $10^{\circ} \mathrm{C}$ & Literature \\
\hline$Y_{X H / S S}$ & 0.67 & 0.67 & $0.38-0.75$ \\
\hline$f p$ & 0.08 & 0.08 & - \\
\hline$i X_{B}$ & 0.09 & 0.09 & - \\
\hline$i X_{P}$ & 0.06 & 0.06 & - \\
\hline$Y_{\mathrm{NO}_{3}} / X A$ & 0.24 & 0.24 & $0.07-0.28$ \\
\hline$\mu_{\max H} \quad\left(\mathrm{~d}^{-1}\right)$ & 6.00 & 3.00 & $0.60-13.20$ \\
\hline$\mu_{\max A}\left(\mathrm{~d}^{-1}\right)$ & 0.80 & 0.30 & $0.20-1.00$ \\
\hline $\mathrm{k}_{\mathrm{dH}}\left(\mathrm{d}^{-1}\right)$ & 0.62 & 0.20 & $0.05-1.60$ \\
\hline $\mathrm{k}_{\mathrm{dA}}\left(\mathrm{d}^{-1}\right)$ & 0.20 & 0.10 & $0.05-0.20$ \\
\hline$K_{S}\left(\mathrm{mgL}^{-1} \mathrm{COD}\right)$ & 20.00 & 20.00 & $5-225$ \\
\hline$K_{O H}\left(\mathrm{mgL}^{-1} \mathrm{O}_{2}\right)$ & 0.20 & 0.20 & $0.01-0.20$ \\
\hline$K_{\mathrm{NO}_{3}}\left(\mathrm{mgL}^{-1} \mathrm{~N}\right)$ & 0.50 & 0.50 & $0.10-0.50$ \\
\hline $\begin{array}{c}K_{X} \mathrm{mg} \text { COD } \\
(\mathrm{mg} \text { biomass COD) })^{-1}\end{array}$ & 0.03 & 0.01 & - \\
\hline$K_{N H_{4}}\left(\mathrm{mgL}^{-1} \mathrm{~N}\right)$ & 1.00 & 1.00 & - \\
\hline$K_{O A}\left(\mathrm{mgL}^{-1} \mathrm{O}_{2}\right)$ & 0.40 & 0.40 & $0.40-2.00$ \\
\hline$k_{h}(\mathrm{mg} \text { biomass COD d })^{-1}$ & 3.00 & 1.00 & - \\
\hline$k_{a N} \mathrm{~L}(\mathrm{mg} \text { biomass COD d })^{-1}$ & 0.08 & 0.04 & - \\
\hline$\eta_{g}$ dimensionless & 0.80 & 0.80 & $0.60-1.00$ \\
\hline$\eta_{h}$ dimensionless & 0.40 & 0.40 & - \\
\hline
\end{tabular}

Source: Jeppsson, U (1996)

before they start to increase afterward. The ammonium nitrogen will decrease earlier when it is not included as limiting parameter of the model. Considering the increase of ammonium nitrogen, it can be predicted that some algae may show up during the treatment processes. If the domestic waste contains high concentration of such nutrient, then being accumulated with the end products of this technology, the algae will grow faster. As presented in Figure 4, the algae were identified to be enormous spread along the water surface of Xuxi River during biological treatment process within June to August 2009.

When the model is simulated under different water temperature, i.e. $10{ }^{\circ} \mathrm{C}$ and $20{ }^{\circ} \mathrm{C}$, slower biodegradation process is presented at lower water temperature. As the bacteria work more active under higher temperature, more dissolved oxygen will be required (Figure 5). As shown in Figure 6, addition of oxygen at the initial stage of treatment process will basically enhance the rate of bacterial growth and removal of COD.

Besides the oxygen would contribute faster biodegradation, the dispersion or mixing parameter also plays crucial role to the process. As both substrate and bacteria will be moderately dispersed to the downstream as the dispersion coefficient increases, longer distance will be required for the recovery of dissolved oxygen concentration

Table 2. Characteristics of natural stream.

\begin{tabular}{cc}
\hline Characteristics of natural stream & Value \\
\hline Stream flow rate, $Q_{r}\left(\mathrm{~m}^{3} \mathrm{~s}^{-1}\right)$ & 0.50 \\
Stream flow velocity, $u_{x}\left(\mathrm{~ms}^{-1}\right)$ & Eq. (12) \\
Dispersion coef, $E_{x}\left(\mathrm{~m}^{2} \mathrm{~s}^{-1}\right)$ & Eq. (11) \\
Reaeration rate, $k_{a}\left(\mathrm{~d}^{-1}\right)$ & Eq. (13) \\
Stream COD $\left(\mathrm{mgL}^{-1}\right)$ & 20.00 \\
Stream soluble nitrate $N\left(\mathrm{mgL}^{-1}\right)$ & 1.00 \\
Stream soluble ammonia $N\left(\mathrm{mgL}^{-1}\right)$ & 1.00 \\
Stream DO, $C r\left(\mathrm{mgL}^{-1}\right)$ & 5.00 \\
\hline
\end{tabular}

Source: Ministry of Environmental Protection of the People's Republic of China and General Administration of Quality Supervision, Inspection and Quarantine of the People's Republic of China (2002).

Table 3. Characteristics of domestic wastewater.

\begin{tabular}{cc}
\hline Characteristics of domestic wastewater & Value \\
\hline Domestic wastewater flow rate, $Q_{w}\left(\mathrm{~m}^{3} \mathrm{~s}^{-1}\right)$ & $0.3 \mathrm{Qr}$ \\
Readily biodegradable COD of wastewater, $S_{S}\left(\mathrm{mgL}^{-1}\right)$ & 115.00 \\
Slowly biodegradable COD of wastewater, $X_{S}\left(\mathrm{mgL}^{-1}\right)$ & 150.00 \\
Dissolved oxygen of wastewater, $C\left(\mathrm{mgL}^{-1}\right)$ & 0.00 \\
Soluble nitrate N of wastewater, $S_{N O_{3}}\left(\mathrm{mgL}^{-1}\right)$ & 0.00 \\
Soluble ammonia N of wastewater, $S_{N H_{4}}\left(\mathrm{mgL}^{-1}\right)$ & 25.00 \\
Soluble biodegrad. org. N of wastewater, $S_{N D}\left(\mathrm{mgL}^{-1}\right)$ & 0.00 \\
Particulate biodegrad. org. N of wastewater, $X_{N D}\left(\mathrm{mgL}^{-1}\right)$ & 0.00 \\
\hline
\end{tabular}

Source: Wiesmann, et al. (2007).

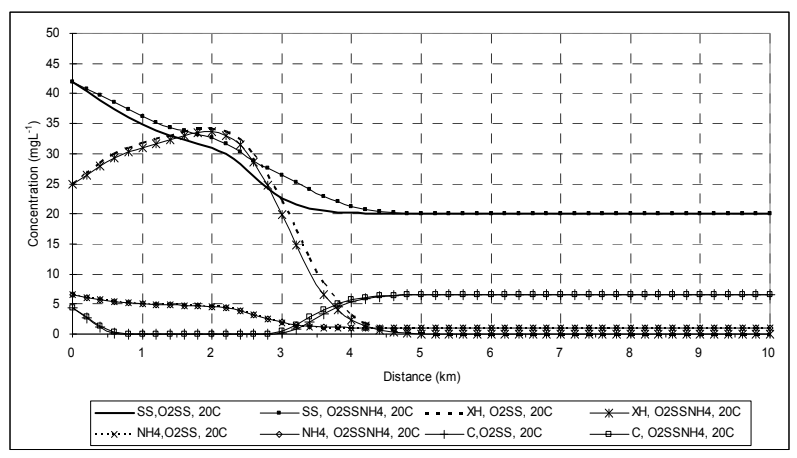

Figure 1. Concentrations of readily biodegradable COD $\left(S_{S}\right)$, heterotrophs $\left(X_{H}\right)$, ammonium nitrogen $\left(S_{N_{4}}\right)$, and dissolved oxygen $(C)$ for channel with $S_{o}=\mathbf{0 . 0 0 0 0 1}$ under different limiting parameters. 


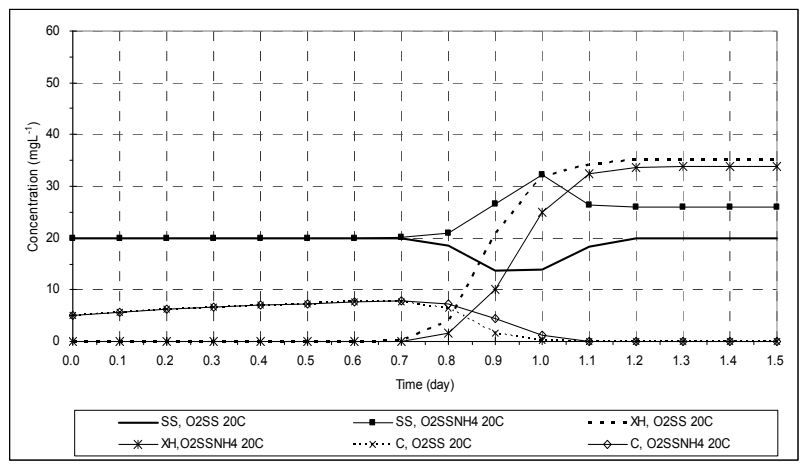

Figure 2. Transient concentrations of readily biodegradable COD $\left(S_{S}\right)$, heterotrophs $\left(X_{H}\right)$, and dissolved oxygen $(C)$ for channel with $S_{o}=\mathbf{0 . 0 0 0 1}$ under different limiting parameters.

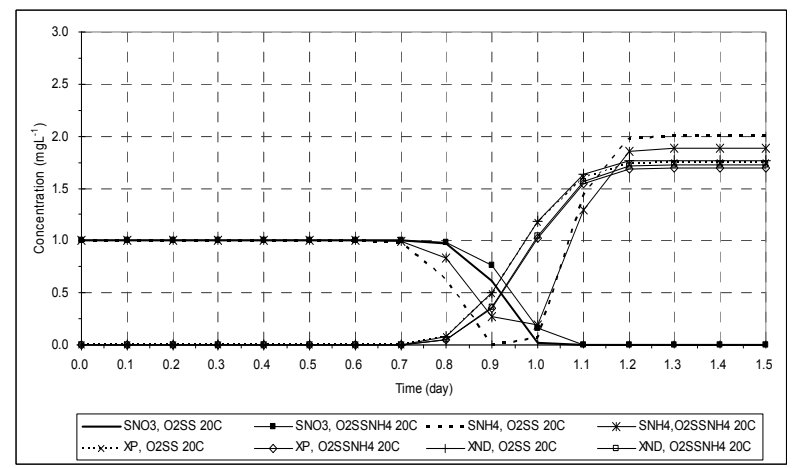

Figure 3. Transient concentrations of nitrate-N ( $\left.S_{\mathrm{NO}_{3}}\right)$, ammonium-N $\left(S_{\mathrm{NH}_{4}}\right)$, particulate products from COD decay $\left(X_{P}\right)$, and particulate degradable organic nitrogen $\left(X_{N D}\right)$ for channel with $S_{o}=\mathbf{0 . 0 0 0 1}$ under different limiting parameters.
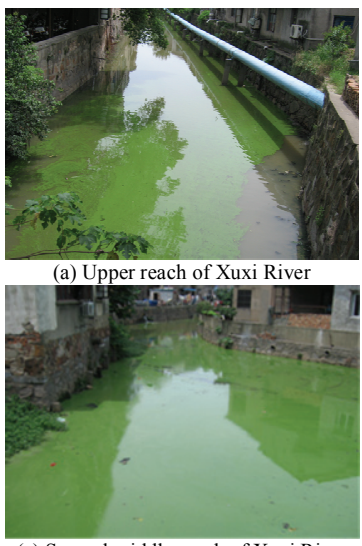

(c) Second middle reach of Xuxi River
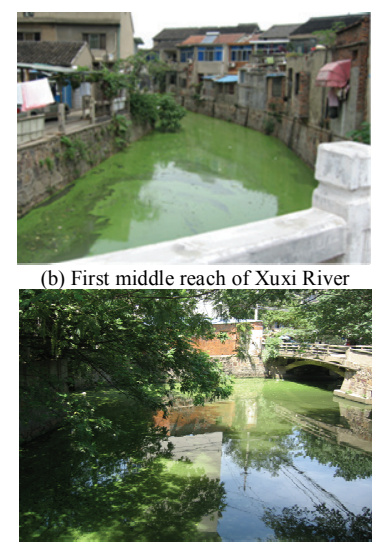

(d) Lower reach of Xuxi River
Figure 4. Algae spread along the water surface of Xuxi River during biological treatment.

in the river (Figure 7). In practical application, the presence of different dispersion coefficient for each variable modelled will play a crucial role in association with various degree of artificial mixing employed during the process of biological river restoration. As described in
Figure 8, when higher longitudinal dispersion coefficient applied, the bacteria will start growing at 0.5 day. Lower peak of COD concentration will also occur due to this faster biodegradation.

\section{Conclusions}

By adopting the concept of stream self purification and activated sludge process, the simulation results showed

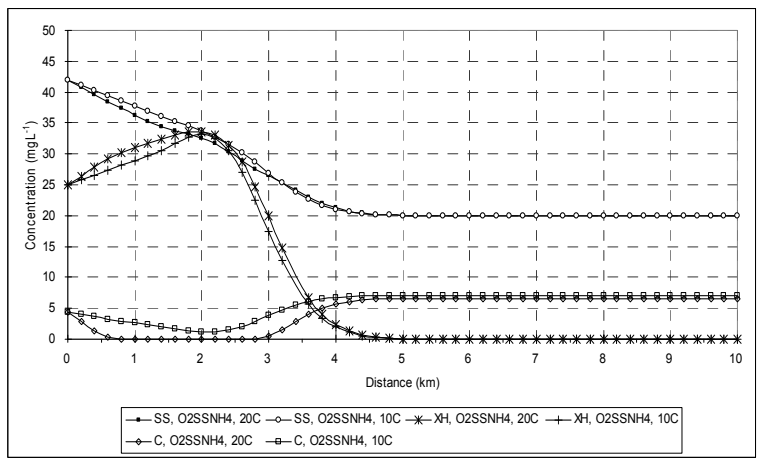

Figure 5. Concentrations of readily biodegradable COD $\left(S_{S}\right)$, hete- rotrophs $\left(X_{H}\right)$, and dissolved oxygen $(C)$ for channel with $S_{o}=0.0001$ under different water temperature.

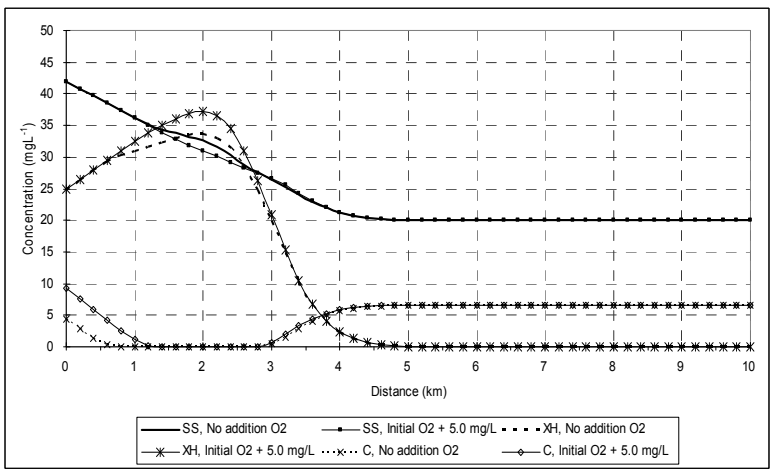

Figure 6. Concentrations of readily biodegradable COD $\left(S_{S}\right)$, hete- rotrophs $\left(X_{H}\right)$, and dissolved oxygen $(C)$ for channel with $S_{o}=0.0001$ under different initial oxygen concentration.

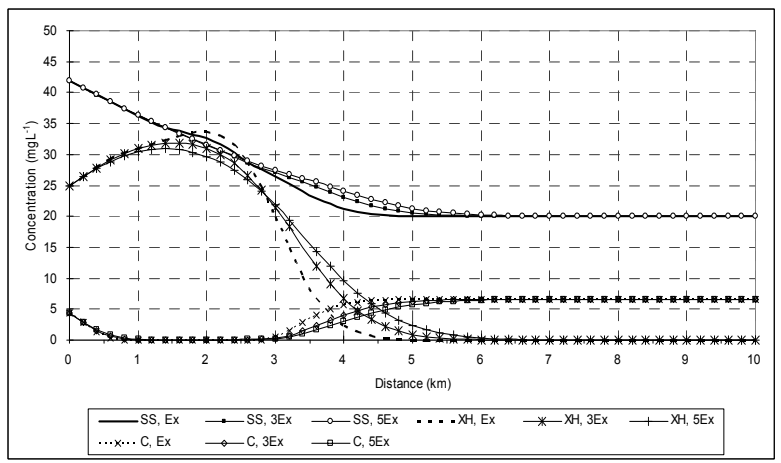

Figure 7. Influences of various values of mixing parameter to the biodegradation process applied to milder channel. 


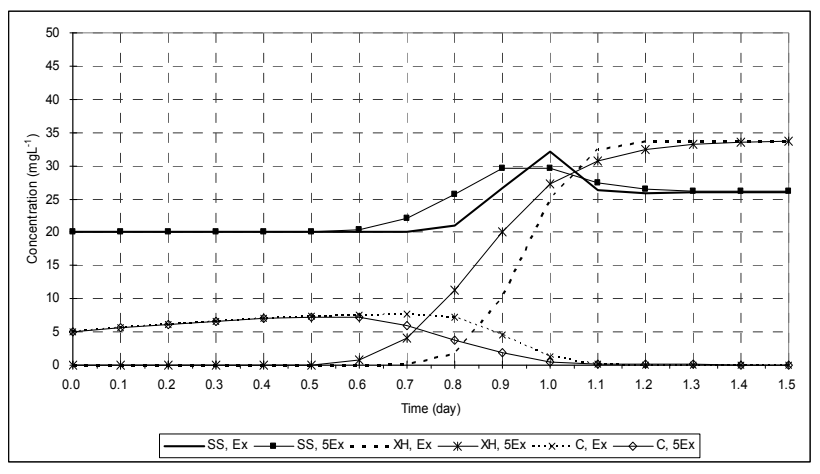

Figure 8. Transient concentrations of readily biodegradable COD $\left(S_{S}\right)$, heterotrophs $\left(X_{H}\right)$, slowly biodegradable COD $\left(X_{S}\right)$, and dissolved oxygen $(C)$ under various dispersion values and modified limiting parameters.

that there are some challenges to effectively apply the technology of bacteria for treating the polluted stream:

- When the ammonium nitrogen is added as limiting parameter to the bacterial growth, under neutral $\mathrm{pH}$ and temperature of $20{ }^{\circ} \mathrm{C}$, the model showed that the COD concentration increases at certain period and is plotted higher at the end. Besides having additional values of some parameters such as particulate products from COD decay and particulate degradable organic nitrogen, the ammonium nitrogen will also increase after it reaches the lowest concentration.

- As consequence of having more ammonium nitrogen, there is a potency that algae may show up during the treatment process. This phenomenon is in fact strongly supported by some evidences obtained from the practical works of such technology under restoration and monitoring project of Xuxi River within June to August 2009.

- Under lower water temperature, the model simulations showed slower biodegradation process.

- Longer distance is required for the recovery of dissolved oxygen as the dispersion coefficient increases. Because of limited oxygen available in polluted stream, extra oxygen injected to the water column at the beginning of treatment may somehow help better bacterial growth and faster biodegradation processes.

- Although the alkalinity has not being modelled in this study yet, but it is realized that $\mathrm{pH}$ would influence the activity of bacteria and some equilibria. In addition, some toxic pollutants may also resist the growth of bacteria. Sediment, as previously reported in many works, is a crucial parameter to be included in the model especially for better understanding of nitrification process. In further research works, diversity of heterotrophs and the effects of limitations of nitrogen, phosphorus and other inorganic nutrients on the removal of organic substrate and on cell growth must also be considered.

- As soon as the field data is completely collected, calibration and validation of the model are crucial to be done.

\section{References}

[1] K. V. Ellis, "Surface water pollution and its control," the Macmillan Press Ltd, London, 1989.

[2] G. H. Jirka and V. Weitbrecht, "Mixing models for water quality management in rivers: Continuous and instantaneous pollutant releases," in P. M. Rowinski and W. Czernuszenko, Eds., "Water quality hazards and dispersion of pollutants," Springer, New York, pp. 1-34, 2005.

[3] M. Campolo, P. Andreussi, and A. Soldati, "Water quality control in the river Arno, technical note," Water Resources, Vol. 36, No. 10, pp. 2673-2680, 2002.

[4] P. R. Kannel, S. Lee, Y. S. Lee, S. R. Kanel, and G. J. Pelletier, "Application of automated QUAL2Kw for water quality modeling and management in the Bagmati River, Nepal," Ecological Modelling, Vol. 202, No. 3-4, pp. 503-517, 2007.

[5] D. Yudianto and Y. B. Xie, "The feasibility of bacteria application for treating the polluted urban stream from the perspective of numerical modelling," in Press for Polish Journal of Environmental Studies, 2010.

[6] I. Gupta, S. Dhage, A. A. Chandorkar, and A. Srivastav, "Numerical modeling for thane creek," Environmental Modelling and Software, Vol. 19, No. 6, pp. 571-579, 2004.

[7] A. K. Misra, P. Chandra, and J. B. Shukla, "Mathematical modeling and analysis of the depletion of dissolved oxygen in water bodies," Nonlinear Analysis: Real World Applications, Vol. 7, No. 5, pp. 980-996, 2006.

[8] M. Green, I. Safray, and M. Agami, "Constructed wetlands for river reclamation: Experimental design, start-up and preliminary results," Bioresource Technology, Vol. 55, No. 2, pp. 157-162, 1996.

[9] S. R. Jing, Y. F. Lin, D. Y. Lee, and T. W. Wang, "Nutrient removal from polluted river water by using constructed wetlands," Bioresource Technology, Vol. 76, No. 2, pp. 131-135, 2001.

[10] D. F. Juang and P. C. Chen, "Treatment of polluted river water by a new constructed wetland," International Journal of Environmental Science and Technology, Vol. 4, No. 4, pp. 481-488, 2007.

[11] J. B. Zhou, M. M. Jiang, B. Chen, and G. Q. Chen, "Emergy evaluations for constructed wetland and conventional wastewater treatments," Communications in Nonlinear Science and Numerical Simulation, Vol. 14, No. 4, pp. 1781-1789, 2007.

[12] Z. M. Chen, B. Chen, J. B. Zhou, Z. Li, Y. Zhou, X. R. $\mathrm{Xi}, \mathrm{C}$. Lin, and G. Q. Chen, "A vertical subsurface-flow constructed wetland in Beijing," Communications in Nonlinear Science and Numerical Simulation, Vol. 13, No. 9, pp. 1986-1997, 2008.

[13] H. S. Cheng, M. K. Yusoff, B. Shutes, and M. Mansor, "Nutrient removal in a pilot and full scale constructed wetland, Putrajaya city, Malaysia," Journal of Environ- 
mental Management, Vol. 88, No. 2, pp. 307-317, 2008.

[14] Q. Y. Nie, Y. B. Xie, J. Zhuang, and L. L. She, "Cyanobacter ia control using microorganism," World Sci-Tech Research and Development," Vol. 30, No. 4, pp. 430-432, 2008.

[15] J. Liao, Y. B. Xie, X. C. Zong, and G. J. Cao, "Pilot study on treatment of complicated chemical industrial effluent with CABRM process," Pollution Control Technology, Vol. 21, No. 1, pp. 11-15, 2008.

[16] D. Yudianto and Y. B. Xie, "Numerical modelling perspectives on the identification of initial challenges of polluted urban stream restoration using bacterial technology," Submitted to International Journal of Environmental Research, unpublished.

[17] Q. H. Wu, R. D. Zhang, S. Huang, and H. J. Zhang, "Effects of bacteria on nitrogen and phosphorus release from river sediment," Journal of Environmental Sciences, Vol. 20, pp. 404-412, 2008.

[18] J. Kiusalaas, "Numerical method in engineering with MATLAB," Cambridge University Press, New York, 2005.

[19] S. M. Libelli, G. Pacini, C. Barresi, E. Petti, and F. Sinacori, "An interactive georeferenced water quality model," in Proceedings of the Fifth International Conference on Hydroinformatics, IWA Publishing and the Authors, Cardiff, UK, pp. 451-456. 2002.

[20] E. Holzbecher, "Environmental modelling using MATLAB," Springer, Berlin, 2007.

[21] M. Yuceer, E. Karadurmus, and R. Berber, "Simulation of river streams: Comparison of a new technique with QUAL2E," Mathematical and Computer Modelling, Vol. 46, No. 1, 2, pp. 292-305, 2007.

[22] D. Yudianto and Y. B. Xie, "Contaminant distribution under non-uniform velocity of steady flow regimes," Journal of Applied Science in Environmental Sanitation, Vol. 3, No. 1, pp. 29-40, 2008.

[23] D. Yudianto and Y. B. Xie, "The development of simple DO sag curve in lowland non-tidal river using MATLAB," Journal of Applied Science in Environmental
Sanitation, Vol. 3, No. 2, pp. 80-98, 2008.

[24] D. Yudianto and Y. B. Xie, "A comparison of some numerical methods in solving 1-D steady state advection dispersion reaction equation by using MATLAB," Online Published in Civil Engineering and Environmental System, In Press for 2010.

[25] S. M. Kashefipour and R. A. Falconer, "Longitudinal dispersion coefficients in natural channels," Water Research, Vol. 36, No. 6, pp. 1596-1608, 2002.

[26] S. Wallis and R. Manson, "On the theoretical prediction of longitudinal dispersion coefficients in a compound channel," In W. Czernuszenko and P. M. Rowinski, Eds., "Water quality hazards and dispersion of pollutants," Springer, New York, pp. 69-84, 2005.

[27] U. Jeppsson, "Modelling aspects of wastewater treatment processes," Ph.D. Dissertation, Lund Institute of Technology, ISBN 91-88934-00-4, 1996.

[28] U. Wiesmann, I. S. Choi, and E. M. Dombrowski, "Fundamentals of biological wastewater treatment," WilleyVCH Verlag Gmbh \& Co. KGaA, Weinheim, 2007.

[29] G. L. Jones, "A mathematical model for bacterial growth and substrate utilization in the activated sludge process," in A. James, Ed., "Mathematical models in water pollution control," John Willey and Sons, Avon, pp. 265-279, 1978.

[30] J. L. Schnoor, "Environmental modeling: Fate and transport of pollutants in water, air, and soil," John Wiley and Sons, New York, 1996.

[31] G. Pelletier and S. Chapra, "A modeling framework for simulating river and stream water quality," Environmental Assessment Program, Olympia, Washington, pp. 98504-7710, 2006.

[32] Ministry of Environmental Protection of the People's Republic of China and General Administration of Quality Supervision, Inspection and Quarantine of the People's Republic of China, Environmental Quality Standard of People's Republic of China for Surface Water (GB38382002), Beijing, 2002. 